\title{
Resenha
}

\section{Comentário sobre o Manual de técnica psicanalítica: uma re-visão, de David E. Zimerman*}

Nazur Aragonez de Vasconcellos**

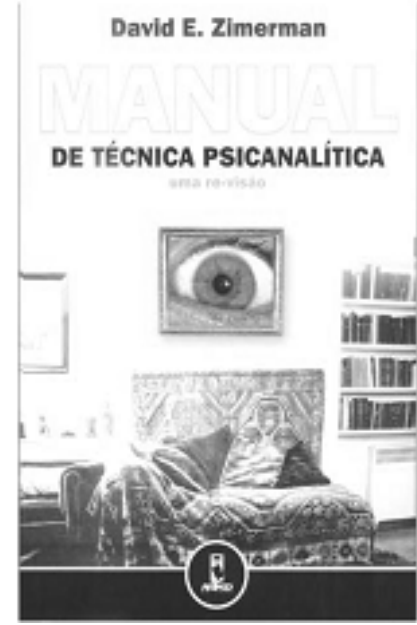

Considero David Zimerman, sem exagero, uma pessoa pública. Não apenas por sua vasta obra científica de alta qualidade, mas também por seu brilhante desempenho em palestras, conferências, seminários teóricos, cursos, grupos de estudo, por suas participações nos meios de comunicação, por sua atuação na clínica privada e como professor e supervisor.

Nas múltiplas atividades exercidas por David Zimerman, evidencia-se uma característica peculiar: a facilidade de comunicação. De fato, a habilidade para expressar-se, tanto por meio da escrita quanto oralmente e em público, é uma das características que diferencia este dentre muitos outros autores.

Um primeiro aspecto a observar no Manual de técnica psicanalítica: uma re-visão é a transparência do autor e sua integração com a própria obra. Melhor explicando: a indissociabilidade entre o autor e sua obra evidencia-se através da não-divisão teóricoprática desse texto recheado de vinhetas clínicas ilustrativas. O fato é que percebo, em

\footnotetext{
* Zimerman DE. Manual de técnica psicanalítica: uma re-visão. Porto Alegre: Artmed; 2003

** Psiquiatra, sócio efetivo da SPRS; graduado pelo Instituto de Psicanálise
} da SPPA; professor e supervisor do Instituto Contemporâneo. todos os momentos, a coerência entre o que o David diz, escreve, faz e o que de fato ele é aliás, esta sugestão ao jovem terapeuta é dele: "se você quer identificar um professor, conferencista, supervisor, analista ou a você mesmo, se é autêntico ou falso, procure observar se há coerência entre o que ele fala, faz e o que, de fato, ele é" (p. 455).

Algum esforço é necessário, portanto, para tentar dissociar o autor de sua obra, já que assim como "a essência do analista impõe-se à sua aparência" (p. 86), a essência do David transparece ao longo de seu texto.

Pois bem. O Manual de técnica psicanalítica: uma re-visão é extremamente prático como um "guia" de consulta para as diversas situações clínicas e temas referentes à técnica. O estilo de David Zimerman proporciona uma leitura agradável. O texto é bem escrito e, com elegância, deixa a impressão de uma conversa direta entre o autor e o leitor. A forma peculiar com que ele expõe suas idéias - com profundidade, mas sem excluir um modo didático e simples de falar e escrever - é uma particularidade também encontrada na maior parte dos textos do mestre maior da psicanálise - reconhecível em "Conferências introdutórias sobre psicanálise", em Artigos sobre técnica, e nos 
Casos clínicos de Freud, só para lembrar alguns.

Como prefácio, há "Uma conversa inicial com os leitores", explicando o subtítulo "uma revisão". Zimerman adianta que o texto abrange uma revisão dos temas gerais e específicos da técnica analítica e, ainda, uma nova "re-visão".

Em outras palavras, as quatro décadas de exercício e estudo da psicanálise permitiram a David Zimerman escrever de forma atualizada, com muita propriedade, sobre a evolução da teoria e da técnica psicanalítica, e apresentar sua própria visão como psicanalista. Esta implica a concepção de "pluralidade" como um conceito de valor positivo, pois nenhum paciente "cabe" por inteiro - se é que se pode falar assim - em apenas uma escola ou teoria psicanalítica, e sim "entre" elas e, por vezes, "além" delas. Pois "(...) o que importa é que tudo o que sabemos de psicanálise - teoria ou técnica - vem da clínica, e tudo o que ainda devemos aprender e transformar necessariamente virá da prática clínica" (p. 8).

O livro divide-se em cinco partes e 41 capítulos. A parte I compreende os aspectos gerais da evolução da técnica psicanalítica; o capítulo 3 - "Como agem as terapias analíticas?" - instiga-nos à reflexão, pois contém subtítulos com temas importantíssimos, que se prolongam em outros capítulos. Dentre os temas aludidos eu destacaria "A pessoa real do analista", "O analista como um novo modelo de identificação" e as "Pseudo mudanças". Pareceu-me igualmente muito criativa a imagem dos "dois eixos técnicos: interpretação e 'atitude psicanalítica interna'”, utilizada pelo autor para ilustrar a eficácia terapêutica.

A parte II - "Os fenômenos no campo do vínculo analítico" - aborda, no capítulo 7, "A pessoa real do analista no processo psicanalítico". Nele, o autor convida o leitor para debater duas correntes: na primeira, a matériaprima da análise "fundamenta-se unicamente nas vicissitudes e diferentes configurações do fenômeno transferencial-contratransferencial" (p.85); a outra considera a pessoa real do analista como importante fator concorrente para o êxito analítico ou seu fracasso. Zimerman mostra-se favorável à segunda, e agrega o papel do "analista como um novo modelo de identificação". Igualmente interessante é a sugestão de que, em alguns casos de Freud, Klein e Bion, a maior responsável pelo êxito da análise foi "(...) a atitude psicanalítica interna espelho das condições desses analistas como pessoas reais que eram (...)" (p.94). Por sua vez, o capítulo 10 - "O contra-ego: uma estrutura resistencial patológica" é clinicamente muito útil. Nele o autor designa contra-ego a "uma subestrutura intra-ego", considerando os conceitos embutidos no termo oriundos de autores como Freud, Abraham, R. Sterba, Fairbairn, Winnicott, Bion, Meltzer, Rosenfeld, B. Joseph, J. Steiner e Bollas - a si próprio credita apenas a originalidade do termo. A riqueza do capítulo aparece na ênfase ao dia-adia da clínica (ressaltada por seis belas vinhetas), bem como na sistematização do manejo técnico proposto.

A parte III abrange as "Características clínicas e manejo técnico das diferentes psicopatologias", distribuindo-as em 12 capítulos. De forma sistematizada, o capítulo 25 - "A clínica do vazio" - apresenta a necessária mudança da técnica nessas patologias. Vale registrar que há poucos trabalhos sobre o tema - ao menos com essa denominação -, uma vez que tais patologias pertencem à psicanálise contemporânea. Esta parte se encerra com o capítulo 32 - "Uma forma patológica de amar: o vínculo tantalizante". Além de compreender aquelas formas patológicas de amar caracterizadas por um vínculo de "domínio", "apoderamento", "sedução" e "tantalizante", nas quais há "um irreversível e repetitivo ciclo de promessas, expectativas e decepções, em um perverso dar e tirar (...)" (p. 337), o autor apresenta sugestões técnicas de grande valia na clínica, a meu ver.

A parte IV fala sobre as "Terapias analíticas especiais", abrangendo, no capítulo 33 "Psicanálise com crianças", no 34, "Terapia analítica com púberes e adolescentes", no 35 , "Terapia com casais e famílias", no 36, "Terapia com a família", e no capítulo 37, "Grupoterapia psicanalítica".

A parte V trata de "Situações específicas" em três capítulos - "Vínculos e configurações vinculares", "Reflexões sobre a supervisão analítica" e "Sonhos: manejo técnico" - e também em um "Glossário de conceitos e termos propostos pelo autor".

Encerrando o livro, David, de uma maneira informal e coloquial, disponibiliza toda a sua bagagem de longa vivência de prática analítica em uma belíssima carta íntima para os leitores que estão se iniciando como terapeutas "psicanalíticos".

Utilizando um recurso didático que facilita a leitura do texto, o autor enumera os parágrafos, mantendo uma relativa independência das idéias apresentadas em cada um deles. Dessa forma, em um total de 40 parágrafos, temos, a 
meu ver, um texto de uma riqueza ímpar para os praticantes da psicoterapia analítica, sejam eles iniciantes ou terapeutas nos mais variados graus de desenvolvimento profissional. Pensei que, no mínimo, seria um texto interessante de ler (e reler) ao início, meio e ao cabo dos cursos de formação de terapeutas.

Title: Comments on David E. Zimerman's Manual de técnica psicanalítica: uma re-visão (A Guide to Psychoanalytic Technique: a revision)
Título: Comentario acerca del Manual de técnica psicanalítica: uma re-visão (Manual de técnica psicoanalítica: una re-visión), de David E. Zimerman

Endereço para correspondência:

Nazur Aragonez de Vasconcellos

Rua Iguassú,150/302

CEP 90470-430 - Porto Alegre - RS

E-mail: nazurvas@terra.com.br

Copyright (C) Revista de Psiquiatria do Rio Grande do Sul - SPRS 